\title{
Citizens' Perceptions towards Transportation Tax and Retribution in Malang City, Indonesia
}

\author{
D M Utomo ${ }^{1}$, Astri Warih Anjarwi ${ }^{2}$, Kartika Putri Kumalasari²
}

Received: 14 September 2019 Accepted: 31 January 2020

\begin{abstract}
This paper tries to look at the root cause of low ridership in public transport in the city of Malang, locally known as Angkutan Kota (Angkot), in a kind of non-traditional perspective. The decreasing interest of the people of Malang City towards the use of public transport was presumed partly due to the transportation tax and retribution policies that are somewhat not too restrictive. This study explains that $80 \%$ of people in Malang City consider the amount of Motor Vehicle Tax (PKB) is cheap and reasonable which is believed to drive people away from utilizing Angkot. On the other hand, surprisingly, parking fees for motorized vehicles for most people are considered quite burdensome. Thus, this study suggests that in addition to the need to improve the quality of public transport services, adjusting the amount of tax and the cost of parking for motorized vehicles in the city of Malang needs to be reconsidered to increase the interest of the people of Malang in using public transport.
\end{abstract}

Keyword: transportation, tax, Malang

\section{INTRODUCTION}

Transportation problems that occur in large cities in developing countries, including Indonesia, are often seen in the phenomena of significant increases in private vehicle ownership, changes in movement pattern trends, especially in individual movements, urban land use which is increasingly widespread with the low intensity of development, progress in transportation technology that facilitates mobility but is difficult to integrate with mass transportation, transportation infrastructure that is not well planned and managed so that it cannot accommodate the needs of movement, and less optimal efforts to overcome local problems related to pollution and global warming due to transportation emissions (Dimitriou \& Gakenheimer, 2011).

These phenomena then cause complex transportation problems that are difficult to find a solution: congestion, pollution, traffic accidents, financial deficits, and many problems with regional access (Ortuzar \& Willumsen, 2011). For many big cities, the implementation of mass public transport is one of the popular steps taken by the government to solve these transportation problems. Although it sounds ideal, the implementation of mass public transport is still experiencing many operational constraints, such as conflict with conventional public transport, poor service facilities, relatively expensive transportation rates, all of which accumulate in the low interest of the public to switch from the increasing reliance on private vehicles.

Some urban transportation experts have formulated several factors that influence the choice of one's transport mode. Tamin argues that these factors include characteristics of transport modes, characteristics of travelers, characteristics of travel, urban size, and

\footnotetext{
${ }^{1}$ Department of Regional and Urban Planning, Universitas Brawijaya.

${ }^{2}$ Tax Centre at Faculty of Administration Science, Universitas Brawijaya
}

Korespondensi: dadang.utomo@ub.ac.id 
effective transport policies (Tamin, 2014). Regarding the latter, several previous studies have found that transport policies are the most significant factor for one choosing a mode. In more detail, the transportation policies mentioned in these studies refer to policies related to transportation costs, including the amount of parking retribution, annual motor vehicle tax (PKB), the cost of applying for a driver's license (SIM), the price of fuel (BBM), and ease of financing motor vehicle ownership (Dasan \& Hariyani, 2018; Rahman, Utomo \& Agustin, 2017; Taufiq, Utomo \& Waloeja, 2018). This paper will focus the discussion on parking retribution and annual motor vehicle tax.

The city of Malang is one of the most populous cities in Indonesia, as it is home to many tertiary education facilities, as well as its location being adjacent to Batu Tourism City. The feasibility of providing mass public transport to solve transportation problems has been carried out by researchers and the City Government of Malang, including Bus Rapid Transit (BRT), Cable Car, and Monorail, in addition to Bus School transportation. But unfortunately, so far there is no mass transportation that can reduce the use of private vehicles in the city of Malang. So, more effort from the City Government of Malang to establish a transportation policy that supports the use of public transport modes by the community is very necessary.

One of the oldest form of public transportation available in Malang City is locally known as Angkutan Kota (Angkot), which has been operating since the 1980s. The Angkot is a minibus converted into a 12-passenger vehicle. Poorly maintained fleets, lack of regular operational schedules, low comfort offered, and relatively expensive transportation rates are mentioned to be the cause of the decreasing number of Angkot users, especially after the increasingly popular online-based modes of transportation with all the convenience, comfort, and reliability offered. The Angkots are privately owned, generally by the drivers themselves. While maintaining the vehicle is expensive, it has been a great pressure for the business-owners to provide even decent service to passengers in a regulated inflexible route. Moreover, other transport options such as the online-based transport service (Go-jek, Gocar, Grab) offers more attractive services, with credit to a better management system.

The tariff of Angkot in Malang is regulated according to the Malang Mayor Regulation number 6 in 2015. Currently, the Angkot tariff is set at IDR 4,000 per trip. Whereas for private vehicle operations, parking retribution fees are regulated in Malang City Regulation number 3 of 2015 amounting to Rp. 3,000 for 4-wheeled motorized vehicles and Rp. 2,000 for 2-wheeled vehicles. Annual tax costs for 2-wheeled vehicles vary from $\mathrm{Rp} 200,000$ per year, while 4 -wheel vehicles start at Rp 1,750,000 per year, depending on the type of engine, type of fuel, and type of vehicle.

The initial assumption of this study is that the cost of transportation for private vehicles in the city of Malang is cheaper than the transportation costs of using public transportation, so that people prefer to use private vehicles. Therefore, more specifically, this study aims to identify people's perceptions of the amount of PKB and parking costs, as well as its influence on the willingness of the community to use public transportation.

Parking deposits in Malang City are one of the components in Malang City's Original Regional Revenue (PAD) whose collection is grouped through retribution income, which is managed by the Malang City Transportation Agency, as well as the taxes being managed by the Regional Tax Revenue Agency (BP2D). Although its contribution is not as big as other PAD components, revenue from the parking sector has an equally important role in regional development. Especially in the current era of regional autonomy, each Regional Government has full authority in regulating parking income policies to fulfill its PAD. But quite unfortunate, the amount of parking fees currently set is disproportionate to the increase in motorized vehicle ownership, so there is still a lot of potential revenue that should be obtained by the Regional Government from the vehicle parking sector (Dewi, 2013). 
In addition to parking fees, $\mathrm{PKB}$ is also another component in $\mathrm{PAD}$. The amount subjected to $\mathrm{PKB}$ is determined based on the level of road damage, environmental pollution on the use of motorized vehicles, as well as the subject and object of PKB. The utilization of PKB by the Regional Government can be done as one of the sources of regional income, financing the administration of local government, funding the construction of funds or road maintenance and increasing modes and means of public transportation, helping to increase Regency / City revenues, and increasing legal peace and certainty for taxpayers (Okta, 2009)

\section{RESEARCH METHOD}

This study employs a descriptive quantitative approach in describing people's perceptions of $\mathrm{PKB}$ and motor vehicle parking retribution in the city of Malang. With the same method, this study tries to describe the influence of these policies towards public interest in using public transportation in the city of Malang. In filling out the research questionnaire, respondents were asked to give their opinions regarding the annual $\mathrm{PKB}$ amount and parking fees they had to pay to the City Government of Malang. Other question that was also asked is how far, nominally, the public is still willing to bear the $\mathrm{PKB}$ costs and parking fees before moving to use mass public transportation.

In total, the selected respondents are 400 respondents, 200 of which own twowheeled vehicles, while the other 200 own four-wheeled vehicles. Respondents were taken randomly at the centers of trading and service activities (Olympic Garden Mall, Malang Town Square, Malang City Point, and Plaza Araya), offices, and universities during the period from 16 to 28 August 2018.

\section{RESULT AND DISCUSSION}

Transportation problems in the city of Malang, also in other big cities, are basically caused by the number of motorized vehicles that far exceed the limits of existing road infrastructure capacity. According to the data from the Statistics Agency, the number of motorized vehicles, both motorcycles and cars and other large vehicles, reached $63.4 \%$ of the total population of Malang City in early 2017. While the addition of road infrastructure has barely changed from year to year (Arifin, 2018)

The implementation of mass public transportation is considered a logical and feasible effort to achieve a balance between the number of vehicles and road capacity, because the number of private vehicles can be significantly reduced. Plans for developing mass public transportation, according to the Barenlitbang of Malang City, include Bus Rapid Transit, Monorail, and Cable Car. Not only in the city, this mass public transportation will also serve the regional area of Malang, which includes Malang City, Malang Regency, and Batu City. The implementation of mass public transport is certainly inseparable from the risk of whether or not people want to use it. This challenge appears to see the decline in public interest in using Angkot.

Based on the amount from the Malang City Transportation Agency in 2014, the number of Angkot registered was 2,192 fleets which were spread unevenly into 25 transport routes (Putri, 2015). Physically, Angkot is a minibus produced in the 1980s that was modified to be able to accommodate 11-12 passengers. The age of the old vehicle invited many complaints from the people of Malang City towards the low quality of Angkot service. Moreover, operational performance of Angkot is considered to be less than optimal: long mileage, unpredictable waiting time, low movement speed, and poor driver driving capability. In addition to the poor operational performance, the uneven distribution and the low quality of services have encouraged more convenient and inexpensive use of private vehicles and ojek and taxi online. 
Transportation costs are generally formed by daily expenditures to reach the destination, including transportation, parking, vehicle tax and fuel tariffs (Martínezespiñeira, \& Amoako-tuffour, 2009). Transportation costs as a whole have a negative correlation to the choice of mode of transportation by someone, which means if the cost of transporting a mode is higher, one will tend to choose other modes that are cheaper (Tamin, 2014)

The amount of the Angkot tariff in Malang City is determined through the Malang Mayor Regulation number 6 in 2015, which is IDR 4,000 and IDR 2,000 respectively for public and students. This tariff is flat, which means it does not depend on the distance traveled. Although many think that this tariff is quite cheap, according to (Putri, 2015), spending on Angkot costs in the city of Malang can reach Rp. 24,000 per day, considering that Angkot service routes are not comprehensive so one has to switch routes and other modes to continue the journey.

Unlike the case with Angkot, transportation costs incurred using private vehicles are relatively cheaper. The costs for BBM and $\mathrm{PKB}$ are accumulative in a certain time, generally a week and a year, so that the expenditure does not overload the community. Meanwhile, parking costs which are incidental in nature with a high frequency of expenditure in a day are considered to be sufficient to burden the daily transportation costs that must be incurred. Because the pricing of BBM is supervised and determined by the Central Government, this research will only consider the costs for PKB and Parking which the determination and management are within the authority of the Malang City Government.

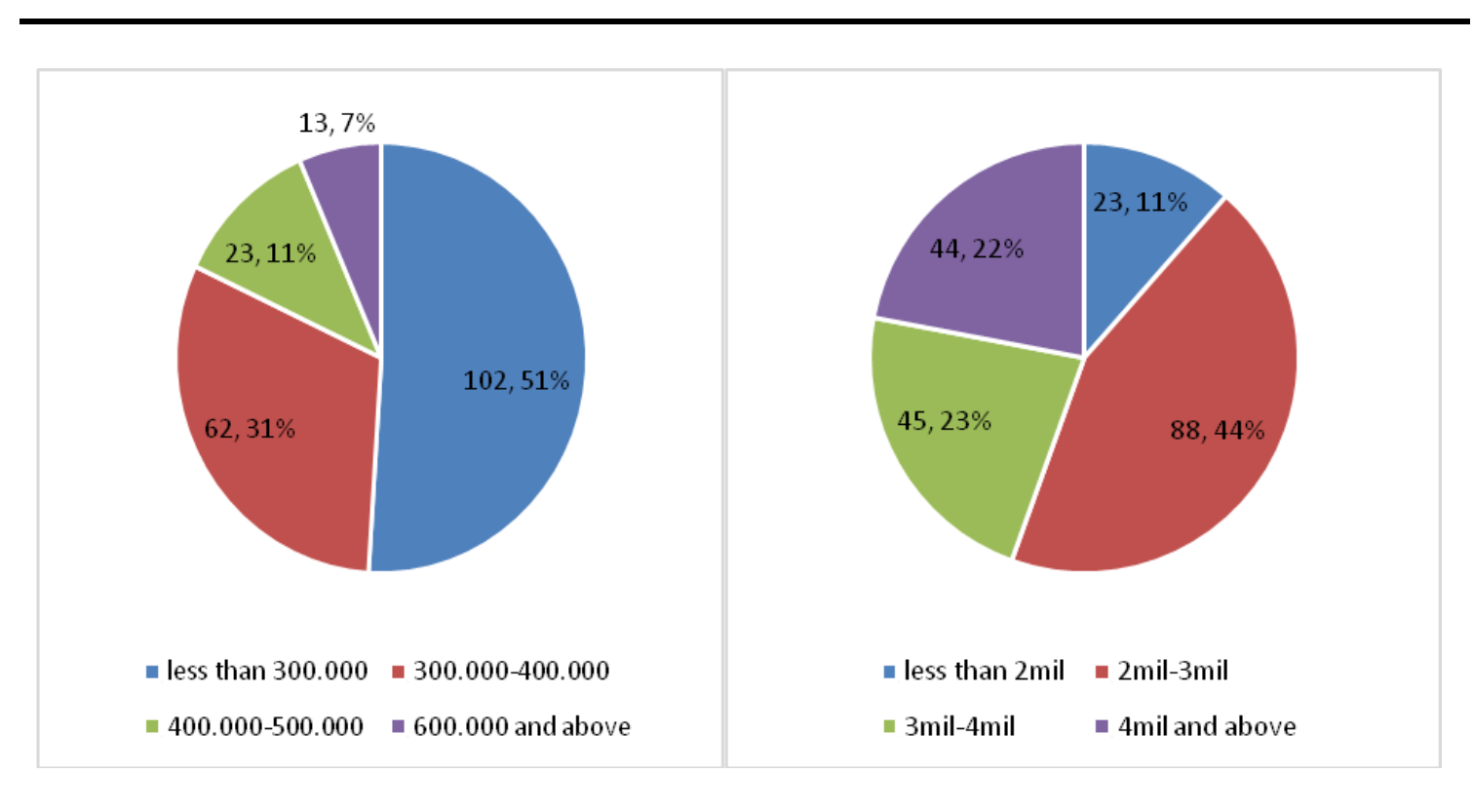

Figure 1. Annual Taxes for Motorcycle (Left) and Car (Right)

\section{DISCUSSION}

Figure 1 illustrates the amount of $\mathrm{PKB}$ showing that in the majority, the $\mathrm{PKB}$ of Motorcycle in Malang City ranges from under Rp. 300,000 while the PKB of the car ranges from Rp. 2,000,000 and Rp. 3,000,000. In more detail, as seen in Figure 2, the majority of 2 -wheel motorized voters consider that the amount of CLA is currently cheap, while the majority of owners of 4-wheeled vehicles consider the amount of PKB currently competitive. These results indicate that in general, the people of Malang City consider that 
the determination of $\mathrm{PKB}$ in Malang City is quite reasonable and not financially burdensome. Some conditions that can be used as justifications for this are:

1. The monthly fee for annual taxes is relatively low when compared to the costs that must be incurred for the current use of city transportation. Take the motorbike PKB mode of Rp. 300,000 and a car of Rp 2,500,000, the monthly PKB fee that must be paid is Rp. 25,000 and Rp 208,500 each for motorbikes and cars.

2. The process of arranging tax payments is now very easy, even the payment location has been opened in the centers of the crowd, so that the community is not too burdened with the PKB payment obligations.

Unlike the PKB elements that are considered not burdensome to the community, setting parking rates based on survey results shows a higher burden for the community.

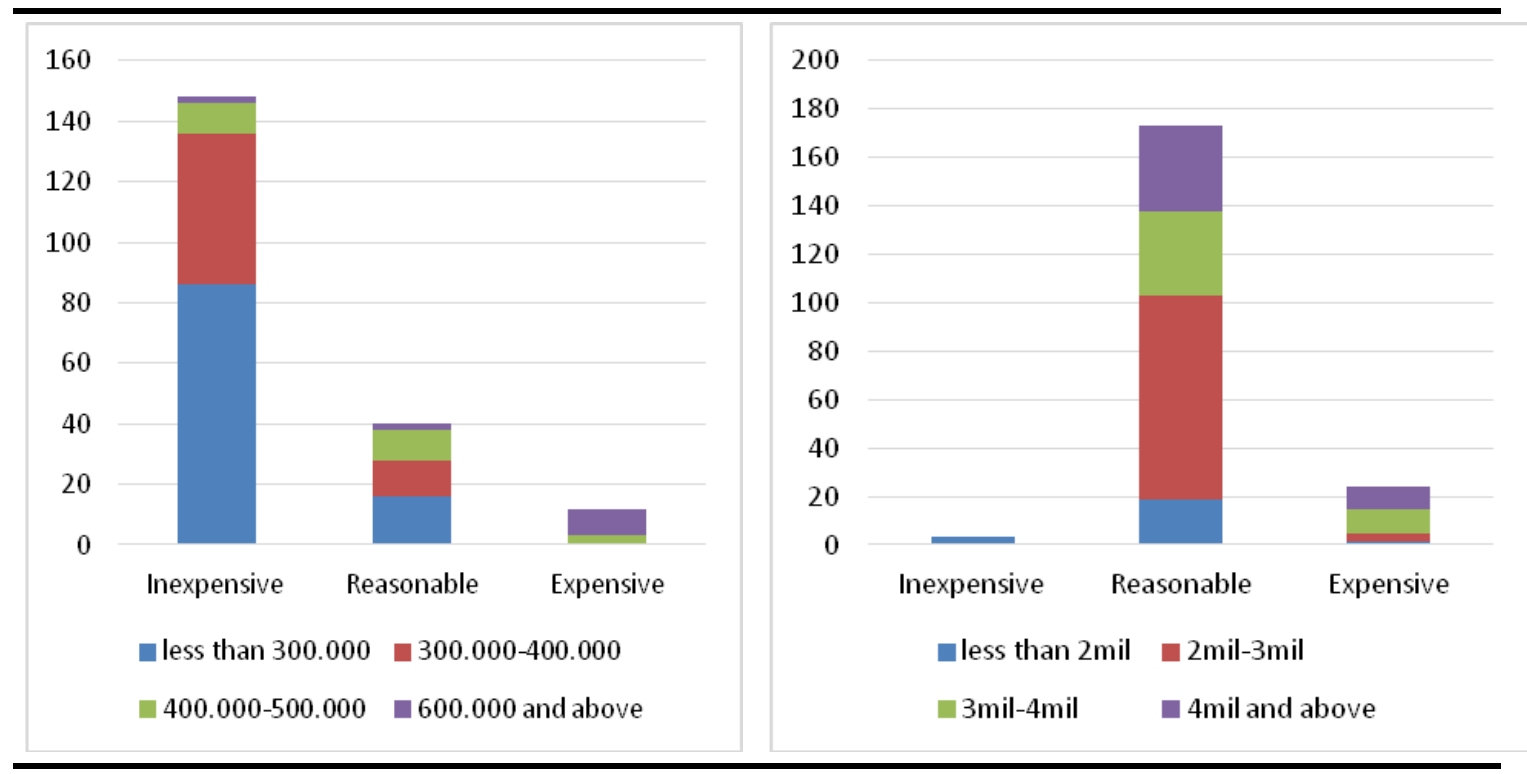

Figure 2. Respondents' Perception Towards Vehicle Annual Tax: Motorcycles (Left), Cars (Right)

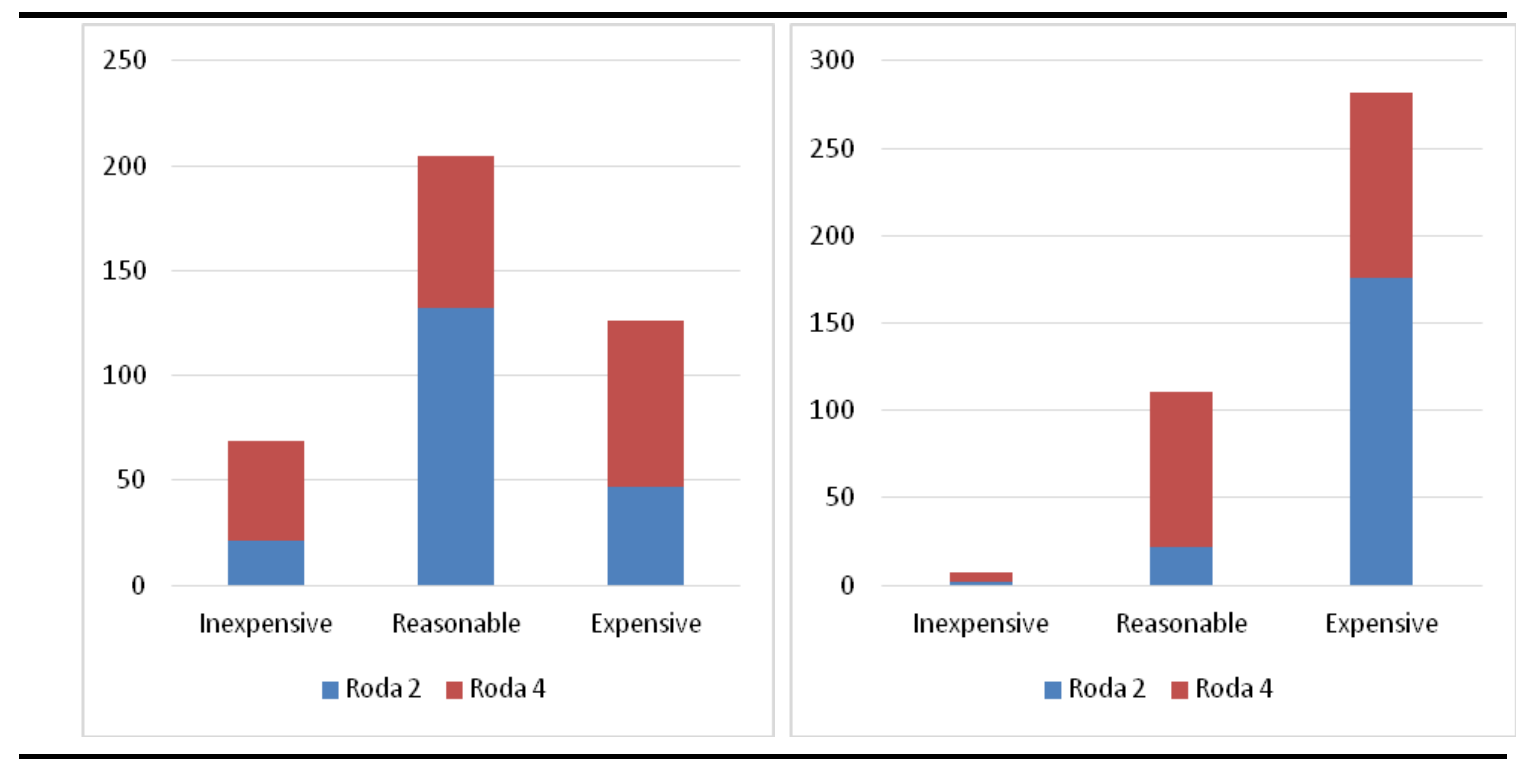

Figure 3. Respondents' Perceptions Toward The Current Parking Tariffs (Left) and The Two-Fold Increase Assumption (Right) 
Figure 3 above shows some of the following: parking fees are currently considered fair to expensive by most people. This is most likely due to the cost of parking fees being carried out many times a day, so that accumulatively, the expenditure of parking fees is the biggest transportation cost component for the people of Malang City. Increased parking fees doubled (Rp. 4,000 for motorbikes and Rp. 6,000 for cars) have shown significant differences in community perceptions. Most car users consider parking costs to be expensive, while motorcycle users still consider that the rates are reasonable.

This significant change in perception shows that the effect of parking tariff arrangements has a greater forced power compared to PKB arrangements. So, it can be estimated that changes in motor vehicle parking rates affect more to the community's willingness to move towards public transportation, if one day the City Government of Malang provides mass public transportation that meets the criteria of community demand.

After knowing the perception of the people of Malang City on each component of $\mathrm{PKB}$ and parking fees for motorized vehicles, the following is a comparison between the transportation costs incurred by the average community of Malang City using private vehicles and public transportation.

Table 1. Comparison of incurred costs for each transportation mode

\begin{tabular}{|c|c|c|c|}
\hline & 4-Wheeled Vehicle & 2-Wheeled Vehicle & Angkot \\
\hline Annual Tax $\left.{ }^{* * *}\right)$ & 5,480 & 734 & \\
\hline Parking $* *)$ & 15,000 & 10,000 & - \\
\hline Fuel*) $^{*}$ & 23,400 & 7,800 & 24,000 \\
\hline Angkot Tariff & & & 4,000 \\
\hline Total & 43,480 & 18,534 & 28,000 \\
\hline
\end{tabular}

*) Based on the assumption of Pertalite price per Oktober $1^{\text {st }}, 2018$ of IDR 7,800/litre

$* *$ Based on the assumption of sample daily parking mode, 5 times per day with flat tariff (non-progressive)

$* * *$ ) Based on the assumption of motorized vehicle tax mode per day

Judging from the Table 1 above, it can be concluded that generally, transportation cost incurred in Malang City is still relatively lower when using private vehicle, be it 4wheeled vehicles or 2-wheeled vehicles. By closely observing public's perception towards PKB and parking fees, it can be estimated that the citizens of Malang City might be more inclined to use Angkot when there is an increase in PKB and parking fees. However, City Government of Malang needs to maintain their effort to actualize mass public transportation that caters the need of the public.

Based on survey and analysis result, the development plan for mass public transportation in Malang City needs to take transportation policy aspect, aside from careful route and operational planning process. Investment made for mass public transportation procurement must be anticipated in order to achieve break-even point as soon as possible through optimal use by every aspect of the public. Fundings for the development of mass public transportation mode require the participation from private and donors, so that they are able to provide subsidies for a more affordable tariffs which will attract public's interest in using it.

\section{CONCLUSION}

Transportation policy per some previous studies has a significant contribution in determining the choice of urban community mode. The survey results showed that the low cost of transportation by using private vehicles in the city of Malang, including annual taxes, parking, and fuel, caused people to still be reluctant to use Angkot, likely due to fleet conditions and operational services that are still weak. The magnitude of the influence of transportation cost policy established by both the City Government of Malang and the Central Government (fuel) on the selection of private vehicle modes in the community 
indicated that the planning of mass public transport in the city of Malang, in addition to paying attention to mature route planning and operations, also need to pay attention to the possibility of financing investment to achieve sufficient public transport subsidies, so that the tariff charged to the community per unit of transport becomes affordable and attracts high public interest.

Because of the limited resources in this study, there is a need for a follow-up effort by considering the economic aspects of the city as well as others, to obtain public transportation tariff rates that are of interest to the people of Malang City.

\section{ACKNOWLEDGEMENT}

The authors would sincerely thank the Lembaga Penelitian dan Pengabdian Masyarakat (LPPM) Universitas Brawijaya for its financial support through the Hibah Peneliti Pemula (HPP) 2018 scheme. The survey and research throughout the construction of this paper will also not be possible without the help and support from students of the Department of Regional and Urban Planning Universitas Brawijaya (PWK-UB) as well as the Tax Centre team of the Faculty of Administration Science Universitas Brawijaya (FIAUB).

\section{REFERENCES}

Dimitriou, H. T., \& Gakenheimer, R. (2011). Urban Transport in the Developing World: A Handbook of Policy and Practice. Edward Elgar Publishing.

Ortuzar, J. d., \& Willumsen, L. G. (2011). Modelling Transport: Edition 4. John Wiley \& Sons.

Tamin, O. Z. (2014). Metode Estimasi Matriks Asal-Tujuan (MAT) untuk Peramalan Kebutuhan Transportasi: Teori, Contoh Soal, dan Aplikasi. Bandung: Penerbit ITB.

Dasan, M. R., Utomo, D. M., \& Hariyani, S. (2018). Model Pemilihan Moda Bus Sekolah Bagi Pelajar di Kota Malang. Planning for Urban Region and Environment.

Rahman, M. I., Utomo, D. M., \& Agustin, I. W. (2017). Probabilitas Pemilihan Moda Antara Kendaraan Pribadi dengan Transportasi Air Kota Banjarmasin. Planning for Urban Region and Environment.

Taufiq, D. N., Utomo, D. M., \& Waloeja, B. S. (2018). Pemilihan Moda Kereta Gantung pada Rute Perjalanan Kota Malang-Kota Batu. Planning for Urban Region and Environment.

Dewi, S. R. (2013). Peranan Retribusi Parkir dalam Meningkatkan Pendapatan Asli Daerah Kota Magelang. Yogyakarta: Universitas Atma Jaya Yogyakarta.

M.P, R. O. (2009). Tinjauan Atas Tata Cara Pemungutan Pajak Kendaraan Bermotor Dinas Pendapatan Daerah di Provinsi Jawa Barat. Bandung: Fakultas Ekonomi Universitas Widyatama.

Arifin, Z. (2018, March 3). Jumlah Kendaraan Hampir Separuh Penduduk Kota Malang. Retrieved from Liputan 6: https://www.liputan6.com/regional/read/3337501/jumlah-kendaraan-hampir-separuhpenduduk-kota-malang

Putri, R. K. (2015). Alternatif Program Peningkatan Minat Masyarakat Terhadap Angkutan Umum Trayek LDG di Kota Malang. Malang: Jurusan Perencanaan Wilayah dan Kota Universitas Brawijaya.

Martínez-espiñeira, R., \& Amoako-tuffour, J. (2009, June). Multi-Destination and Multi-Purpose Trip Effects in the Analysis of the Demand for Trips to a Remote Recreational Site. Environmental Management, 43(6), 1146-61. 